\title{
Kontribusi power lengan, power tungkai, daya apung, dan fleksibilitas terhadap renang gaya crawl 50 meter
}

\author{
Muhamad Ukon Prawirakusuma ${ }^{1 *}$, Pamuji Sukoco ${ }^{2}$ \\ ${ }^{1}$ SD Negeri Serayu Yogyakarta, Jalan Juadi, Kotabaru, Gondokusuman, Yogyakarta 55224, Indonesia \\ ${ }^{2}$ Fakultas Ilmu Keolahragaan Universitas Negeri Yogyakarta \\ Jalan Colombo No. 1, Karangmalang, Yogyakarta, 55281, Indonesia \\ *Corresponding Author. Email: muhamadukon7@yahoo.com
}

\begin{abstract}
Abstrak
Penelitian ini bertujuan untuk mengetahui: (1) kontribusi power lengan terhadap prestasi renang gaya crawl 50 Meter, (2) kontribusi power tungkai terhadap prestasi renang gaya crawl 50 Meter, (3) kontribusi daya apung terhadap prestasi renang gaya crawl 50 Meter, (4) kontribusi fleksibilitas terhadap prestasi renang gaya crawl 50 Meter, (5) kontribusi dan hubungan power lengan, power tungkai, daya apung dan fleksibilitas terhadap prestasi renang gaya crawl 50 Meter. Penelitian ini merupakan penelitian survei dengan desain korelasional. Subjek penelitian ini yaitu atlet renang putra DIY. Teknik pengambilan sampel menggunakan purposive sampling dengan total responden sebanyak 20 orang. Instrumen pengumpulan data menggunakan tes pengukuran. Analisis data menggunakan regresi berganda. Hasil penelitian menunjukkan: (1) ada kontribusi power lengan terhadap prestasi renang gaya $\mathrm{crawl} 50$ Meter ( $p$ value $=0,016$ ) dengan kontribusi sebesar 18,9\%. (2) Ada kontribusi power tungkai terhadap prestasi renang gaya crawl 50 Meter ( $p$ value $=0,046)$ dengan kontribusi sebesar 28,6\%. (3) Ada kontribusi daya apung terhadap prestasi renang gaya crawl 50 Meter ( $p$ value $=0,019)$ dengan kontribusi sebesar 26,3\%. (4) Ada kontribusi fleksibilitas terhadap prestasi renang gaya crawl 50 Meter ( $p$ value $=0,009$ ) dengan kontribusi sebesar 17,8\%. (5) Kontribusi power lengan, power tungkai, daya apung dan fleksibilitas terhadap prestasi renang gaya crawl 50 Meter pada atlet renang putra DIY sebesar 91,6\%. Kesimpulan: Ada kontribusi Power Lengan, Power Tungkai, Daya Apung dan Fleksibilitas terhadap Prestasi Renang Gaya Crawl 50 Meter pada Perenang Putra DIY.
\end{abstract}

Kata kunci: power lengan; power tungkai; daya apung; fleksibilitas; prestasi renang gaya crawl $50 \mathrm{M}$

\section{The contribution of arm power, leg power, buoyancy, and flexibility to the swimming of crawl stroke $50 \mathrm{M}$}

\begin{abstract}
This research aimed to find out: the contribution of (1) arm power, (2) leg power, (3) buoyancy, (4) flexibility, and (5) relationship of arm power, leg power, buoyancy, and flexibility to the swimming performance of crawl stroke 50 Meter.This research is a survey research study with correlational design. The subjects of this research are DIY's male swimming athletes. The sampling technique on this research is purposive sampling with 20 person total of respondents. Data collection instrument used tests. The data analysis used multiple regressions. The results of this research indicate that: there is contribution of arm power to the swimming performance of crawl stroke 50 Meter ( $p$ value $=0.016$ ) with $18.9 \%$ of contribution. There is contribution of leg power to the swimming performance of crawl stroke 50 Meter ( $p$ value $=0.046$ ) with $28.6 \%$ of contribution. There is contribution of buoyancy to the swimming performance of crawl stroke 50 Meter ( $p$ value $=0.019)$ with $26.3 \%$ of contribution. There is contribution of flexibility to the swimming performance of crawl stroke 50 Meter ( $p$ value $=0.009$ ) with $17.8 \%$ of contribution. The Contribution of arm power, leg power, buoyancy, and flexibility to the swimming performance of crawl stroke 50 Meter on DIY's male swimmer athlete is $91.6 \%$. The rest which are 8,4\% was another factors.
\end{abstract}

Keywords: arm power; leg power; buoyancy; flexibility; swimming performance of crawl stroke $50 \mathrm{M}$ 


\section{PENDAHULUAN}

Aktivitas olahraga dewasa ini telah berkembang pesat. Olahraga dilakukan dengan berbagai tujuan. Kegiatan olahraga terbagi menjadi olahraga kesehatan, olahraga pendidikan, olahraga prestasi, dan olahraga rekreasi. Olahraga prestasi ditekankan pada pencapaian prestasi tinggi. Olahraga dalam tujuan prestasi telah dikelola dalam lembaga yang profesional untuk mencapai prestasi tinggi. Olahraga prestasi diarahkan pada upaya untuk meraih prestasi seperti pemecahan rekor atau pencapaian gelar juara.

Salah satu cabang olahraga yang dikembangkan menjadi olahraga kompetisi adalah olahraga renang. Cabang olahraga renang merupakan salah satu cabang olahraga populer baik di tingkat nasional maupun internasional. Salah satu buktinya adalah cabang olahraga renang menjadi salah satu cabang olahraga yang wajib ada pada kompetisi olahraga tingkat dunia yaitu Olimpiade.

Pencapaian prestasi olahraga renang dapat dicapai dengan baik, dimulai dengan pembinaan atlet sejak usia dini. Pembinaan atlet berfungsi untuk menyiapkan atlet yang berkemampuan tinggi yang dapat mencapai prestasi maksimal pada usia emasnya. Pembinaan prestasi olahraga renang tidak terlepas dari peran pelatih, yang ditunjang dengan sumber daya manusia, sarana dan prasarana, sumber dana, dan metode pembinaan yang tepat dan disertai dengan menajemen organisasi yang profesional. Seluruh komponen tersebut merupakan satu kesatuan untuk melakukan pembinaan prestasi olahraga.

Komponen sumber daya manusia berhubungan dengan kualitas atlet yang dibina. Atlet renang merupakan ujung tombak pencapaian prestasi olahraga renang, sehingga seorang atlet dituntut untuk memunyai kemampuan teknik dan kondisi fisik yang baik. Olahraga renang merupakan salah satu cabang olahraga yang menggunakan seluruh anggota badan, sehingga dibutuhkan kemampuan biomotorik untuk dapat melakukan gerakan renang dengan baik. Kemampuan bimotorik dan kondisi fisik akan memudahkan atlet dalam melakukan gerakan renang yang kompleks.

Salah satu jenis gaya yang ada dalam renang adalah gaya crawl atau gaya bebas. Dalam melakukan renang gaya ini dibutuhkan penguasaan teknik berenang yang baik. Atlet harus menguasai teknik dasar gaya crawl atau gaya bebas. Teknik dasar tersebut adalah: posisi tubuh di air atau mengapung, gerakan kaki atau mengayun kaki, mengayuh atau gerakan tangan, koordinasi tangan dan kaki, dan sistem pernapasan (Thomas, 2000, p.13). Selain itu dibutuhkan pula kemampuan power, daya apung, dan fleksibilitas sehingga dihasilkan gerakan yang efektif dan efisien.

Power merupakan komponen fisik yang sangat berpengaruh terhadap laju gerakan renang. Kekuatan dan kecepatan merupakan faktor utama terbentuknya power yang dimiliki seseorang. Dalam olahraga renang power digunakan untuk mencapai kecepatan maksimal. Power yang dibutuhkan meliputi power lengan dan power tungkai. Power lengan digunakan untuk melakukan gerakan mengayun, sedangkan power tungkai dibutuhkan untuk menghasilkan daya dorong ke depan.

Kekuatan otot dalam olahraga renang memunyai peranan yang penting. Setiap kecepatan maju dalam berenang adalah hasil dari dua kekuatan yaitu: (1) kekuatan untuk menahan disebut hambatan yang disebabkan oleh air yang harus didesak maju; (2) kekuatan yang mendorongnya maju disebut dorongan yang diperoleh dari gerakan atau tarikan lengan dan dorongan tungkai. Kekuatan dalam hal ini kekuatan otot lengan dan otot tungkai, secara bersama berperan dalam menghasilkan gerakan maju dalam berenang.

Daya apung dibutuhkan untuk dapat memermudah badan agar sejajar dengan permukaan air. Sikap mengapung di air dengan prinsip bahwa sesuatu yang ringan akan lebih mudah mengapung, sehingga orang yang ringan tidak banyak memperoleh hambatan apabila dibandingkan dengan orang yang berat badannya besar. Kemampuan mengapung dalam berenang sangat penting karena akan mempermudah dalam mencapai gerak yang lebih cepat.

Fleksibilitas dalam renang gaya bebas dibutuhkan untuk melakukan gerakan-gerakan ke semua arah secara optimal. Kelentukan merupakan keluasan gerak suatu persendian agar dalam melakukan gerak atau aktivitas tubuh lebih efisien. Gerakan renang gaya bebas membutuhkan tubuh dan sendi yang fleksibel, untuk menghasilkan gerakan renang yang cepat. Fleksibilitas juga berfungsi untuk mengurangi cidera pada otot dan sendi, sehingga dapat mendukung perkembangan dan pencapaian prestasi olahraga renang.

Pembinaan prestasi olahraga renang tidak melulu pada penguasaan teknik yang benar, tetapi harus dilatih juga pada kemampuan biomotorik dan kemampuan pendukung renang seperti daya apung. Aspek kemampuan fisik, kemampuan pendukung dan teknik merupakan satu kesatuan yang 
saling melengkapi satu dengan yang lain dalam pencapaian prestasi olahraga renang. Kenyataan di lapangan masih banyak pelatih lebih menekankan pada teknik dan mengabaikan kemampuan biomotorik maupun kemampuan pendukung. Program latihan yang diterapkan pelatih lebih banyak fokus kepada teknik, karena kemampuan biomotorik dan pendukung dianggap sebagai modal dasar yang telah dimiliki oleh atlet, sehingga hanya diberikan dengan porsi yang relatif sedikit.

Berdasarkan latar belakang masalah di atas, dapat disimpulkan bahwa pencapaian prestasi renang tidak hanya berhubungan dengan penguasaan teknik berenang, melainkan juga pada kemampuan biomotorik diantaranya power dan fleksibilitas. Selain itu renang juga membutuhkan komposisi tubuh diantaranya daya apung. Penulis tertarik untuk melakukan penelitian tentang "Kontribusi power lengan, power tungkai, daya apung dan fleksibilitas terhadap prestasi renang gaya crawl 50 Meter pada perenang putra DIY".

\section{METODE}

Penelitian ini merupakan penelitian deskriptif korelasional metode survei dengan tes pengukuran. Penelitian korelasional menurut Arikunto (2002, p.239) adalah penelitian yang bertujuan untuk menemukan ada tidaknya hubungan dan apabila ada seberapa eratnya hubungan serta berarti atau tidak hubungan itu. Dikatakan termasuk dalam kategori korelasional karena penelitian ini mencari data ada tidaknya hubungan antara satu variabel dengan variabel yang lain dan kalau ada dicari seberapa jauh dengan pengambilan data secara survei mengunakan metode tes pengukuran.

Populasi dalam penelitian ini adalah seluruh perenang putra DIY dengan jumlah 30 orang. Teknik sampling dalam penelitian ini adalah purposive sampling yaitu teknik pengambilan sampel penggunakan kriteria tertentu. Kriteria sampel penelitian ini adalah sebagai berikut: (a) Atlet putra yang tercatat sebagai perenang DIY; (b) Pernah mengikuti kejuaraan minimal tingkat daerah; (c) Tidak sedang mengalami cedera saat pengambilan data penelitian. Sampel dalam penelitian ini berjumlah 20 orang.

Menurut Arikunto (2002, p.194) instrumen penelitian adalah alat bantu yang digunakan dalam pengambilan data penelitian. Instrumen dalam penelitian ini adalah sebagai berikut: (a) Pulldown/tricep extention test, untuk mengukur power lengan; (b) Cable cross over, untuk mengukur power tungkai; (c) Tes menggunakan alat ukur geser, untuk pengambilan data flexsibility; (d) Tes daya apung, untuk mengukur daya apung atlet; (e) Tes renang gaya crawl 50 meter, untuk mengukur prestasi renang gaya crawl, dengan menggunakan instrumen pendukung yaitu stop watch untuk mengukur waktu tempuh renang gaya crawl.

Metode pengumpulan data merupakan cara untuk memperoleh data yang akan diperlukan dalam penelititan. Penelitian ini menggunakan metode survei dengan teknik tes dan pengukuran. Survei adalah suatu pendekatan penelitian yang pada umumnya digunakan untuk pengumpulan data yang luas dan banyak (Arikunto, 2002, p.90). Sedangkan tes menurut Arikunto (2002, p.127) adalah serentetan pertanyaan atau latihan serta alat lainyang digunakan untuk mengukur keterampilan, pengetahuan intelegensi, kemampuan atau bakat yang dimiliki individu atau kelompok.

Teknik analisis data yang digunakan dalam penelitian ini yaitu uji normalitas dilakukan untuk mengetahui apakah data memunyai sebaran yang berdistribusi normal. Uji yang digunakan adalah uji Kolmogorov Smirnov. Uji lineritas dilakukan untuk menguji gejala hubungan variabel bebas dengan variabel terikat. Pengujian pengaruh power lengan, power tungkai, daya apung, fleksibilitas dengan variabel terikat yaitu prestasi renang gaya crawl 50 meter yang digunakan teknik analisis regresi ganda.

\section{HASIL DAN PEMBAHASAN}

\section{Perhitungan Normalitas}

Tabel 1. Hasil Uji Normalitas Data

\begin{tabular}{lccc}
\hline \multicolumn{1}{c}{ Hasil pukulan forehand } & KSZ & $p$ & Ket. \\
\hline Power lengan & 0,756 & 0,617 & Normal \\
Power tungkai & 0,474 & 0,978 & Normal \\
Daya apung & 0,519 & 0,950 & Normal \\
Fleksibilitas & 0,755 & 0,620 & Normal \\
Prestasi renang gaya crawl $50 \mathrm{M}$ & 0,912 & 0,376 & Normal \\
\hline
\end{tabular}




\section{JORPRES (Jurnal Olahraga Prestasi), 15 (1), 2019 - 31}

Muhamad Ukon Prawirakusuma, Pamuji Sukoco

Tabel 1 menunjukkan bahwa hasil perhitungan normalitas data pretes diperoleh nilai signifikansi lebih besar dari 0,05 ( $p>0,05)$, maka dapat dinyatakan bahwa data penelitian ini berdistribusi normal. Artinya sebaran data penelitian ini memenuhi kriteria kurva kenormalan data sebagai syarat analisis statistik parametrik.

Tabel 2. Hasil Uji Linieritas

\begin{tabular}{lccc}
\hline \multicolumn{1}{c}{ Hubungan } & F hitung & $p$ & Ket. \\
\hline $\mathrm{X} 1 \rightarrow \mathrm{Y}$ & 0,876 & 0,554 & Linier \\
$\mathrm{X} 2 \rightarrow \mathrm{Y}$ & 2,185 & 0,130 & Linier \\
$\mathrm{X} 3 \rightarrow \mathrm{Y}$ & 6,502 & 0,300 & Linier \\
$\mathrm{X} 4 \rightarrow \mathrm{Y}$ & 1,141 & 0,498 & Linier \\
\hline
\end{tabular}

Tabel 2 menunjukkan bahwa hasil perhitungan linieritas hubungan variabel $\mathrm{X}$ dengan $\mathrm{Y}$ diperoleh nilai signifikansi lebih besar dari $0,05(p>0,05)$. Oleh karena nilai signifikansi lebih besar dari 0,05 $(p>0,05)$, maka dapat dinyatakan bahwa hubungan antara variabel X1, X21 X3 dan X4 dengan prestasi renang gaya crawl $50 \mathrm{M}$ adalah linier.

\section{Pengujian Hipotesis}

Tabel 3. Hasil Analisis Regresi Linear Berganda

\begin{tabular}{|c|c|c|c|c|}
\hline Variabel & Koefisien Regresi & t-hitung & Sig. & Keterangan \\
\hline Power lengan & 0,264 & 2,727 & 0,016 & Ha diterima \\
\hline Power tungkai & 0,319 & 2,181 & 0,046 & Ha diterima \\
\hline Daya apung & 0,259 & 2,616 & 0,019 & Ha diterima \\
\hline Fleksibilitas & 0,331 & 3,017 & 0,009 & Ha diterima \\
\hline Konstanta & $:-\overline{8,686}$ & & & \\
\hline $\mathrm{R}^{2}$ & : 0,916 & & & \\
\hline F hitung & $: 41,072$ & & & \\
\hline Sig. & $: 0,000$ & & & \\
\hline
\end{tabular}

Berdasarkan hasil analisis regresi tersebut, maka didapatkan persamaan regresi sebagai berikut: $Y=-8,686+0,264 X_{1}+0,319 X_{2}+0,259 X_{3}+0,331 X_{4}+e$

Uji $t$ (secara parsial)

Hipotesis pertama yang diajukan dalam penelitian ini adalah "Ada kontribusi power lengan terhadap prestasi renang gaya crawl $50 \mathrm{M}$ ". Hasil statistik uji t pada variabel power lengan diperoleh nilai t hitung sebesar 2,727 dengan tingkat signifikansi 0,016 , karena signifikansi lebih kecil dari 0,05 $(p<0,05)$, maka hipotesis diterima. Artinya ada kontribusi yang signifikan power lengan terhadap prestasi renang gaya crawl $50 \mathrm{M}$.

Hipotesis kedua yang diajukan dalam penelitian ini adalah "Ada kontribusi power tungkai terhadap prestasi renang gaya crawl $50 \mathrm{M}$ ". Hasil statistik uji t pada variabel power tungkai diperoleh nilai t hitung sebesar 2,181 dengan tingkat signifikansi 0,046, karena signifikansi lebih kecil dari 0,05 $(p<0,05)$, maka hipotesis diterima. Artinya ada kontribusi yang signifikan power tungkai terhadap prestasi renang gaya crawl $50 \mathrm{M}$.

Hipotesis ketiga yang diajukan dalam penelitian ini adalah "Ada kontribusi daya apung terhadap prestasi renang gaya crawl $50 \mathrm{M}$ ". Hasil statistik uji t pada variabel daya apung diperoleh nilai t hitung sebesar 3,017 dengan tingkat signifikansi 0,009, karena signifikansi lebih kecil dari 0,05 $(p<0,05)$, maka hipotesis diterima. Artinya ada kontribusi yang signifikan daya apung terhadap prestasi renang gaya crawl $50 \mathrm{M}$.

Hipotesis keempat yang diajukan dalam penelitian ini adalah "Ada kontribusi fleksibilitas terhadap prestasi renang gaya $\mathrm{crawl} 50 \mathrm{M}$ ". Hasil statistik uji t pada variabel fleksibilitas diperoleh nilai t hitung sebesar 2,616 dengan tingkat signifikansi 0,019, karena signifikansi lebih kecil dari 0,05 $(p<0,05)$, maka hipotesis diterima. Artinya ada kontribusi yang signifikan fleksibilitas terhadap prestasi renang gaya crawl $50 \mathrm{M}$.

\section{Uji $F$}

Hipotesis kelima yang diajukan dalam penelitian ini adalah "Ada kontribusi power lengan, power tungkai, daya apung, dan fleksibilitas terhadap prestasi renang gaya crawl $50 \mathrm{M}$ ". Uji $\mathrm{F}$ 


\section{JORPRES (Jurnal Olahraga Prestasi), 15 (1), 2019 - 32}

Muhamad Ukon Prawirakusuma, Pamuji Sukoco

digunakan untuk membuktikan secara statistik bahwa keseluruhan variabel penelitian yang digunakan dalam analisis ini berpengaruh signifikan secara simultan. Apabila nilai signifikansi F lebih kecil dari $0,05(p<0,05)$ maka model regresi signifikan. Hasil analisis diperoleh nilai $\mathrm{F}$ hitung sebesar 41,072 dengan signifikansi sebesar 0,000. Oleh karena nilai signifikansi tersebut lebih kecil dari 0,05 $(p<0,05)$, maka hipotesis diterima. Artinya ada pengaruh power lengan, power tungkai, daya apung, dan fleksibilitas terhadap prestasi renang gaya crawl $50 \mathrm{M}$.

\section{Koefisien Determinasi $\left(R^{2}\right)$}

Hasil analisis diperoleh nilai koefisien determinasi $\left(\mathrm{R}^{2}\right)$ sebesar 0,916. Hasil tersebut menunjukkan kontribusi power lengan, power tungkai, daya apung dan fleksibilitas terhadap prestasi renang gaya crawl $50 \mathrm{M}$ sebesar $91,6 \%$ sedangkan sisanya $8,4 \%$ dipengaruhi oleh faktor lain yang tidak diteliti dalam penelitian ini.

Berdasarkan hasil perhitungan pada diketahui dari total kontribusi sebesar 91,6\%, variabel power lengan memberikan kontribusi sebesar 18,9\%, variabel power tungkai memberikan kontribusi sebesar 28,6\%, variabel kekuatan daya apung memberikan kontribusi sebesar 26,3\% dan variabel fleksibilitas memberikan kontribusi sebesar $17,8 \%$. Dapat disimpulkan variabel yang memberikan kontribusi paling besar adalah power tungkai.

\section{Pembahasan}

Hasil analisis statistik membuktikan ada kontribusi singnifikan power lengan terhadap prestasi renang gaya crawl $50 \mathrm{M}$ pada perenang putra DIY ( $p$ value $=0,016$ ). Hal ini menunjukkan bahwa power lengan mempunyai pengaruh dalam pencapaian hasil renang gaya $\mathrm{crawl} 50 \mathrm{M}$. Power lengan merupakan unsur penting dalam renang gaya crawl $50 \mathrm{M}$.

Power lengan mempunyai kontribusi terhadap prestasi renang gaya crawl $50 \mathrm{M}$ dapat dijelaskan karena power lengan merupakan sumber kekuatan yang mampu menggerakkan tubuh melaju ke depan. Komponen utama dari power adalah kekuatan dan kecepatan sehingga dapat menghasilkan energi untuk dapat menggerakkan badan dengan kekuatan maksimal dalam waktu yang cepat. Hasilnya dapat dicapai catatan waktu yang baik dalam renang gaya crawl $50 \mathrm{M}$.

Jarak $50 \mathrm{M}$ merupakan jarak yang pendek, sehingga power menjadi modal utama yang dibutuhkan untuk mencapai catatan waktu terbaik. Renang pada jarak yang dekat hal yang paling dibutuhkan adalah berenang dengan kekuatan dan kecepatan penuh. Power menjadi kunci terbentuknya daya dorong sehingga perenang mampu bergerak dengan cepat dan mencapai hasil renang gaya crawl $50 \mathrm{M}$ yang optimal. Didukung pendapat Salo \& Riewald (2008, p.111) menyebutkan power lengan dalam berenang dapat memaksimalkan dorongan dengan mempercepat tangan dan lengan untuk menghasilkan power.

Power merupakan kemampuan seseorang untuk mempergunakan kekuatan maksimum yang dikerahkan dalam waktu yang sependek-pendeknya. Komponen utama dari power adalah kekuratan dan kecepatan. Kekuatan dan kecepatan merupakan faktor utama yang sangat menentukan baik tidaknya power yang dimiliki oleh atlet. Dalam olahraga renang power akan menghasilkan kekuatan maksimal untuk dapat bergerak dalam waktu yang cepat.

Power lengan berguna untuk penggerak segala kegiatan tubuh. Renang gaya bebas membutuhkan power lengan sebagai tenaga pendorong. Perenang yang mempunyai power lengan untuk menghasilkan daya dorong ke depan. Daya dorong yang dihasilkan oleh power lengan akan menghasilkan laju gerak ke depan yang cepat. Didukung pendapat dari Salo \& Riewald (2008, p.59) menyebutkan power lengan akan menghasilkan kekuatan dan kecepatan yang maksimal untuk mendukung prestasi.

Hasil penelitian ini didukung dengan hasil penelitian sebelumnya yang dilakukan oleh Baron, Dekerle, Depretz, Lefere and Pelayo (2005, p.90) dengan hasil penelitian kayuhan menentukan kecepatan pada renang gaya bebas $400 \mathrm{M}$. Didukung juga dengan teori yang dikemukakan oleh Salo \& Riewald (2008, p.66) menyebutkan kemampuan untuk menghasilkan power secara langsung terkait dengan efisiensi berenang dan kemampuan untuk memaksimalkan kekuatan dorongan dengan mempercepat tangan dan lengan. Power lengan dalam gerakan renang gaya bebas, berperan sebagai pendorong/penggerak disamping juga pengatur keseimbangan tubuh pada saat berenang sehingga dapat dicapai hasil maksimal. 


\section{JORPRES (Jurnal Olahraga Prestasi), 15 (1), 2019 - 33}

Muhamad Ukon Prawirakusuma, Pamuji Sukoco

Hasil analisis data penelitian membuktikan ada kontribusi power tungkai terhadap prestasi renang gaya crawl $50 \mathrm{M}$ pada perenang putra DIY ( $p$ value $=0,046$ ). Hasil ini menunjukkan bahwa power tungkai merupakan faktor yang berpengaruh signifikan dalam pencapaian prestasi renang gaya crawl 50 M. Power tungkai menjadi komponen penting dalam mencapai prestasi renang gaya crawl 50 M.

Hasil tersebut dapat dijelaskan karena power tungkai merupakan salah satu sumber tenaga yang menggerakkan atlet melaju dengan kekuatan dan kecepatan penuh. Power tungkai menjadi tenaga peluncur menghasilkan tenaga yang mendorong maju ke depan. Power tungkai akan menghasilkan kecepatan untuk bergerak maju ke depan. Seperti yang dikemukakan oleh KONI (2003, p.18) disebutkan bahwa power tungkai berfungsi sebagai penggerak maju ke depan. Atlet yang mempunyai power tungkai yang baik, maka akan mempengaruhi kecepatan.

Power tungkai merupakan unjuk kerja dari otot-otot tungkai untuk melakukan gerakan dengan mengarahkan kekuatan dan kecepatan secara maksimal dalam waktu yang singkat. Meliputi seluruh kaki mulai dari pangkal paha ke bawah. Power tungkai digunakan untuk melakukan gerakan menolak, menendang, meloncat dan sebagainya. Power atau daya ledak otot (muscular power) ditentukan oleh kekuatan otot, kecepatan gerakan maksimum, dan aktivasi neomuskular (Moritani dalam Kyriazis et all., 2009, p.173).

Power tungkai hampir dibutuhkan oleh seluruh cabang olahraga termasuk berenang. Power tungkai merupakan salah satu unsur sumber tenaga yang sangat dibutuhkan dalam olahraga renang, Olahraga renang membutuhkan power tungkai sebagai salah satu komponen energi utamanya untuk dapat melaju ke depan. Gerakan renang gaya bebas, membutuhkan kekuatan kaki yang berperan sebagai tenaga peluncur.

Hasil penelitian ini didukung dengan penelitian sebelumnya yang dilkukan oleh McCullough, Amy, Kraemer, William, Jeff, Hill and Hatfield (2009, p.36) diperoleh hasil adanya hubungan potensial antara kelentukan pergelangan kaki dan kekuatan tendangan. Hal ini memungkinkan perpindahan air ke arah belakang menghasilkan tenaga pendorong. Didukung juga dengan teori dari Salo \& Riewald (2008, p.57) menyebutkan renang membutuhkan kekuatan yang dapat mendorong untuk bergerak maju dan power tungkai berfungsi sebagai penggerak maju ke depan.

Hasil analisis membuktikan secara statistik ada kontribusi daya apung terhadap prestasi renang gaya crawl $50 \mathrm{M}$ pada perenang putra DIY ( $p$ value $=0,019$ ). Hasil ini membuktikan bahwa daya apung berperan dalam pencapaian prestasi renang gaya crawl $50 \mathrm{M}$.

Daya apung dapat mempengaruhi prestasi renang gaya crawl $50 \mathrm{M}$ dapat dijelaskan karena saat perenang mempunyai daya apung maka perenang akan menjadi lebih ringan di atas air. Hal ini membuat perenang lebih mudah bergerak. Tubuh juga akan lebih mudah terdorong ke depan sehingga dapat dicapai catatan waktu yang baik.

Daya apung juga membuat perenang lebih gesit dalam bergerak. Perenang juga semakin mudah melakukan gerakan ringan dan meminimalkan hambatan. Kemampuan mengapung dalam berenang sangat penting karena akan mempermudah dalam mencapai gerak yang lebih cepat. Perenang yang ringan mempunyai daya apung yang lebih tinggi dan menimbulkan hambatan lebih sedikit daripada perenang yang lebih berat.

Daya apung disebut juga sebagai kemampuan mengapung dalam air. Daya apung seseorang besarnya sama dengan berat air yang dipindahkan oleh badan yang mengapung. Terdapat beberapa hal yang mempengaruhi daya apung seseorang di dalam air, misalnya densitas tubuh (kapasitas paru-paru, komposisi tubuh) (The Canadian Red Cross Society, 1974, p. 30).

Daya apung sangat dibutuhkan pada renang renang gaya crawl $50 \mathrm{M}$. Jarak tempuh yang relatif pendek menuntut agar perenang bergerak dengan gesit dan cepat tanpa melakukan kesalahan sedikitpun. Adanya daya apung maka perenang menjadi lebih ringan dan dorongan ke depan akan semakin cepat sehingga semakin cepat pula dalam mencapai finis.

Hasil penelitian ini didukung dengan penelitian sebelumnya yang dilakukan oleh McLean \& Hinrinchs (2000, p.15) dengan hasil penelitian ada pengaruh daya apung dengan kemampuan berenang. Didukung juga dengan teori yang dikemukakan oleh Thomas (2000, p.13) menyebutkan kemampuan mengapung dalam berenang sangat penting karena akan mempermudah dalam mencapai gerak yang lebih cepat. Sikap mengapung di air dengan prinsip bahwa sesuatu yang ringan akan lebih mudah mengapung, sehingga dapat mendukung tercapainya prestasi berenang yang semakin baik. 
Hasil analisis data penelitian menunjukkan ada kontribusi fleksibilitas terhadap prestasi renang gaya crawl $50 \mathrm{M}$ pada perenang putra DIY ( $p$ value $=0,009)$. Hasil ini dapat diartikan bahwa fleksibilitas mempunyai pengaruh pencapaian prestasi renang gaya crawl $50 \mathrm{M}$. Fleksibilitas menjadi komponen penting tercapainya prestasi renang gaya crawl $50 \mathrm{M}$.

Hasil tersebut dapat dijelaskan karena saat melakukan gerakan renang, banyak melibatkan gerak persendian. Renang gaya crawl harus dilakukan dengan gerak yang gesit dan cepat. Gerakan renang yang gesit dan cepat hanya dapat dilakukan dengan adanya fleksibilitas tubuh. Kelentukan pada perenang terutama pada sendi-sendi lutut, pergelangan kaki, dan pinggul.

Fleksibilitas memungkinkan perenang mampu bergerak secara leluasa. Adanya fleksibilitas meningkatkan keleluasaan gerak persendian sehingga menghasilkan aktivitas gerak tubuh yang baik. Dalam berenang kelentukan akan membantu dalam mengembangkan kecepatan gerak laju, koordinasi, kelincahan, menghemat pengeluaran tenaga pada waktu melakukan gerakan-gerakan dan membantu menghasilkan gerakan yang efisien. Didukung pendapat dari Irianto (2004, p.4), kelentukan adalah kemampuan persendian untuk bergerak secara leluasa.

Fleksibilitas (flexibility) merupakan kemampuan pergelangan/ persendian untuk dapat melakukan gerakan-gerakan ke semua arah secara optimal. Fleksibilitas membuat seseorang mampu menyesuaikan diri terhadap segala aktivitas gerak tubuh yang dilakukan. Tubuh menjadi mampu melakukan gerakan yang seluas-luasnya akibat dari penguluran maksimal pada otot, ligament dan persendian.

Fleksibilitas sendi berfungsi memaksimalkan pemakaian tenaga menjadi lebih efisien. Gerakan renang yang dilakukan dengan kecepatan membutuhkan tubuh, dan sendi yang fleksibel. Fleksibilitas penting dimiliki perenang dalam melakukan gerakan yang membutuhkan kelentukan dan penting digunakan untuk pencegahan cedera. Didukung pendapat dari Setiawan (2007, p.62) menyebutkan fleksibilitas sangat penting dalam olahraga renang.

Hasil penelitian ini didukung dengan penelitian sebelumnya yang dilakukan oleh McCullough, Amy, Kraemer, William, Jeff, Hill and Hatfield (2009, p.45) dengan hasil penelitian ada hubungan potensial antara kelentukan pergelangan kaki dengan prestasi renang gaya bebas. Didukung juga teori dari Counsilman (Setiawan, 2007, p.62) disebutkan bahwa fleksibilitas sendi bahu dan sendi pergelangan kaki penting dimiliki oleh perenang lebih-lebih pada renang gaya crawl dan gaya kupukupu, kedua sendi tersebut paling berperan, adanya fleksibilitas pada semua sendi memungkinkan pengerahan kekuatan, kecepatan dan koordinasi yang maksimal.

Hasil analisis data penelitian diketahui ada kontribusi power lengan, power tungkai, daya apung dan fleksibilitas terhadap prestasi renang gaya crawl $50 \mathrm{M}$ pada perenang putra DIY $(p=0,000)$. Besarnya kontribusi power lengan, power tungkai, daya apung dan fleksibilitas terhadap prestasi renang gaya crawl $50 \mathrm{M}$ sebesar 91,6\%. Dapat diartikan bahwa power lengan, power tungkai, daya apung dan fleksibilitas mempunyai kontribusi yang besar terhadap pencapaian prestasi renang gaya crawl $50 \mathrm{M}$.

Prestasi tertinggi adalah harapan yang ingin dicapai oleh setiap perenang. Pencapaian prestasi renang perlu didukung oleh komponen fisik maupun teknik. Penguasaan terhadap komponen fisik merupakan modal dasar untuk mencapai prestasi tinggi. Hasil penelitian ini membuktikan power lengan, power tungkai, daya apung dan fleksibilitas mempunyai kontribusi signifikan terhadap prestasi renang gaya crawl $50 \mathrm{M}$.

Hasil penelitian ini berimplikasi bahwa sangat penting bagi perenang untuk mempunyai kemampuan fisik meliputi power lengan, power tungkai, daya apung dan fleksibilitas. Kemampuan tersebut perlu dikembangkan pada perenang. Pengembangan kemampuan dapat dilakukan melakukan disiplin latihan menggunakan metode latihan yang tepat sehingga kemampuan fisik dapat berkembang secara optimal. Penguasaan terhadap komponen fisik meliputi power lengan, power tungkai, daya apung dan fleksibilitas akan mendukung pencapaian prestasi renang menjadi optimal. Sebagaimana diungkapkan oleh Salo \& Riewald (2008: 12), bahwa renang merupakan olahraga full body, membutuhkan gerak yang terkoordinasi dari otot-otot di kaki, inti/pusat, dan tubuh bagian atas dalam setiap langkah yang diambil. Oleh karena itu dibutuhkan kemampuan biomotorik untuk dapat melakukan gerakan renang dengan baik. Kemampuan bimotorik dan kondisi fisik akan memudahkan atlet dalam melakukan gerakan renang yang kompleks sehingga dapat mendukung pencapaian prestasi olahraga renang. 


\section{JORPRES (Jurnal Olahraga Prestasi), 15 (1), 2019 - 35}

Muhamad Ukon Prawirakusuma, Pamuji Sukoco

\section{SIMPULAN}

Ada kontribusi power lengan terhadap prestasi renang gaya crawl 50 Meter pada perenang putra DIY ( $p$ value $=0,016$ ) dengan kontribusi sebesar 18,9\%. Ada kontribusi power tungkai terhadap prestasi renang gaya crawl 50 Meter pada perenang putra DIY ( $p$ value $=0,046$ ) dengan kontribusi sebesar $28,6 \%$. Ada kontribusi daya apung terhadap prestasi renang gaya crawl 50 Meter pada perenang putra DIY ( $p$ value $=0,019$ ) dengan kontribusi sebesar 26,3\%. Ada kontribusi fleksibilitas terhadap prestasi renang gaya crawl 50 Meter pada perenang putra DIY ( $p$ value $=0,009)$ dengan kontribusi sebesar $17,8 \%$. Kontribusi power lengan, power tungkai, daya apung dan fleksibilitas terhadap prestasi renang gaya crawl 50 Meter pada perenang putra DIY sebesar 91,6\%.

\section{DAFTAR PUSTAKA}

Arikunto, S. (2002). Prosedur penelitian suatu pendekatan praktek. Jakarta: Rineka Cipta.

Baron, D., Depretz, L., \& Pelayo. (2005). Self selection speed and maximum lactute steady state speed in swimming. Journal of Sports Medicine and Physical Fitness; Mar 2005; 45, 1; ProQuest.

Irianto, D., P. (2004). Dasar kepelatihan. Yogyakarta: FIK UNY.

KONI. (2003). Latihan kondisi fisik. Jakarta: KONI Pusat.

Kyriazis, T. A., et. all. (2009). Muscular power, neuromuscular activation, and performance in shot put athletes at preseason and at competition period. Journal of Strength and Conditioning Research; Sep 2009; 23, 6.

McCullough, A., Kraemer, William, J., Hill \& Hatfield. (2009). Factors affecting flutter kicking speed in women who are competitive and recreational swimmers. Journal of Strength and Conditioning Research. 23.7 Oktober 2009.

McLean \& Hinrinchs. (2000). Influence if arm position and lung volume on the center of buoyancy of competitive swimmers. Research Quarterly for Exercise and Sport; Jun 2000; 71, 2; ProQuest.

Salo \& Riewald. (2008). Complete conditioning for swimming. USA: Human Kinetics.

Setiawan. (2007). Hubungan kekuatan otot dan fleksibilitas sendi dengan prestasi renang $50 \mathrm{~m}$ gaya kupu-kupu. Jurmal Lembaran Ilmu Kependidikan Jilid 36, No. 1, Juni 2007, hlm. 62.

The Canadian Red Cross Society. (1974). National instruction guide and reference. Canada: The Canadian Red Cross Society.

Thomas, G. D. (2000). Renang tingkat mahir. Diterjemahkan oleh Alfons Palangkaraya, Jakarta: PT. Raja Grafindo PersadaAlat - Alat Tes. 